\title{
The Paleoproterozoic Chibaisong Mafic-Ultramafic Intrusion and Cu-Ni Deposit, North China Craton: SHRIMP Zircon U-Pband Re-Os Geochronology and Geodynamic Implications
}

Han Chun-Ming ${ }^{1 *}$, Wu Fu-Yuan'1, Xiao Wen-Jiao', Zhao Guo-Chun², Ao Song-Jian'1, Zhang Ji-Een', Wan Bo', Qu Wen-Jun ${ }^{3}$ and Du An-Dao ${ }^{3}$

${ }^{1}$ Key Laboratory of Mineral Resources, Institute of Geology and Geophysics, Chinese Academy of Sciences, Beijing 100029, China

${ }^{2}$ Department of Earth Sciences, The University of Hong Kong, Pokfulam Road, Hong Kong, China

${ }^{3}$ National Research Center of Geoanalysis, Beijing, 100037, China

\begin{abstract}
The Chibaisong magmatic Ni-Cu sulfide deposit (Jilin Province, NE China) is located in the Jiao-Liao-Ji Belt of the North China Craton. The ore-bearing mafic-ultramafic intrusions intrude the metamorphic rocks of the lowermost Sidaolazi Formation of the Anshan Group. SHRIMP zircon U-Pb dating gives a maximum depositional age of $2188 \pm$ $8 \mathrm{Ma}(95 \%$ confidence level, MSWD=3.2, $\mathrm{n}=8)$ for the host sedimentary rocks of the Chibaisong deposits. Rhenium and osmium isotopic analyses of $\mathrm{Ni}$-and $\mathrm{Cu}$-bearing sulfide minerals from the deposit have been used to determine the timing of mineralization, the source of osmium, and, by inference, the source of ore metals. Sulfide ore samples have Os and $\mathrm{Re}$ concentrations ranging from 19 to $490 \mathrm{ppb}$ and from 0.47 to $13.97 \mathrm{ppb}$, respectively. Analyses of these data yield a six-point isochron age of $1885 \pm 94 \mathrm{Ma}$. An initial ${ }^{187} \mathrm{Os} /{ }^{188} \mathrm{O}$ s ratio of $0.80 \pm 0.16$ (mean square of weighted deviates $=0.17$ ) and $\delta^{34} \mathrm{~S}$ values of -1.1 to $+0.7 \%$ for the ores, as well as initial ${ }^{87} \mathrm{Sr} /{ }^{86} \mathrm{Sr}$ ratios of $0.703-0.708$ for metalliferous intrusions, suggest a magmatic source for the ores, with the melts dominated by mantle contributions. The Chibaisong intrusion was previously considered to have formed under a post-orogenic extensional setting in the Early Cretaceous. However, our new Re-Os geochronological result indicates that the Chibaisong mafic-ultramafic intrusion, along with the Cu-Ni deposit, was related to a Paleoproterozoic extensional event, not resulting from an Early Cretaceous post-orogenic extension as previously considered.
\end{abstract}

Keywords: Re-Os isotopic dating; $\mathrm{Cu}-\mathrm{Ni}$ deposit; Chibaisong; North China Craton

\section{Introduction}

Observations of the spatial and temporal setting of magmatic nickel sulfide deposits (or camps comprised of multiple deposits) indicate an empirical relationship with major lithospheric boundaries, and more specifically, to craton margins [1]. This relationship remains poorly documented in the scientific literature. The North China Craton (NCC) is the largest nickel producing area in China (Figure 1). Until now, two mines have been in production, and numerous other deposits have been found along the margin of the NCC. Since the discovery of the Jinchuan deposit in 1979, extensive geological exploration has been carried out in the NCC region, which led to the recognition of the NCC as one of the largest nickel-copper provinces in China. Over the last few years, numerous attempts have been made to directly or indirectly determine the ages of the nickel-copper provinces [2-5]. However, the timing of the magmatic and mineralization events and their correlations within the complexes remain unclear

In this study, we present new $\mathrm{U}-\mathrm{Pb}$ zircon and $\mathrm{Re}-\mathrm{Os}$ isotopic data for the mineralized ultramafic body from the eastern coppernickel belt in the Jiao-Liao-Ji Belt of the NCC in order to constrain the timing and origin of the mineralization. These new data provide important insights into understanding the mineralization processes and geodynamic environment of the Chibaisong $\mathrm{Ni}-\mathrm{Cu}$ ore deposit. In addition, an attempt was also made to understand the provenance and geodynamic environment of the NCC copper-nickel province. An understanding of the mineralizing processes and the geodynamics is beneficial for $\mathrm{Ni}-\mathrm{Cu}$ exploration on other mafic-ultramafic bodies in the region and throughout the NCC.

\section{Regional Geology}

The NCC is bound to the north by the Central Asian Orogenic Belt
(CAOB) $[6,7]$ and to the south by the Paleozoic to Triassic QinlingDabie-Sulu orogenic belt $[8,9]$. The CAOB underwent north- south directed subduction, and several episodes of collisions at the Solonker suture during the Palaeozoic and accretionary orogenesis from the late Proterozoic to the Mesozoic $[6,7,10]$. To the south, the Qinling-DabieSulu orogenic belt formed through the continental collision between the NCC and the Yangtze Craton in the Triassic [8] (Figure 1).

The Archean to Paleoproterozoic basement of the NCC has been divided into four microcontinental blocks, named the Yinshan, Ordos, Longgang and Nangrim Blocks (Figure 1), of which the Yinshan and Ordos Blocks are considered to have amalgamated along the EWtrending Khondalite Belt to form the Western Block at 1.95-1.92 Ga [11-14], the Longgang and Nangrim Blocks amalgamated along the Jiao-Liao-Ji Belt to form the Eastern Block at $1.90 \mathrm{Ga}$ [15-21], and finally, the Western and Eastern Blocks collided along the Trans-North China Orogen to form the coherent basement of the North China Craton at $\sim 1.85 \mathrm{Ga}[22-26]$.

The Chibaisong ultramafic-mafic intrusion and associated $\mathrm{Ni}$ -

*Corresponding author: Han Chun-Ming, Key Laboratory of Mineral Resources Institute of Geology and Geophysics, Chinese Academy of Sciences, Beijing, China, Tel: 010-82998522; Fax: 010-62010846; E-mail: cm-han@mail.iggcas.ac.cn

Received February 12, 2014; Accepted February 22, 2014; Published March 02, 2014

Citation: Chun-Ming H, Fu-Yuan W, Wen-JiaoX, Guo-Chun Z, Song-Jian A, et al. (2014) The Paleoproterozoic Chibaisong Mafic-Ultramafic Intrusion and Cu-Ni Deposit, North China Craton: SHRIMP Zircon U-Pband Re-Os Geochronology and Geodynamic Implications. J Geophys Remote Sensing 3: 116. doi:10.4172/21690049.1000116

Copyright: (c) 2014 Chun-Ming H, et al. This is an open-access article distributed under the terms of the Creative Commons Attribution License, which permits unrestricted use, distribution, and reproduction in any medium, provided the original author and source are credited. 
Citation: Chun-Ming H, Fu-Yuan W, Wen-JiaoX, Guo-Chun Z, Song-Jian A, et al. (2014) The Paleoproterozoic Chibaisong Mafic-Ultramafic Intrusion and Cu-Ni Deposit, North China Craton: SHRIMP Zircon U-Pband Re-Os Geochronology and Geodynamic Implications. J Geophys Remote Sensing 3: 116. doi:10.4172/2169-0049.1000116

Page 2 of 8

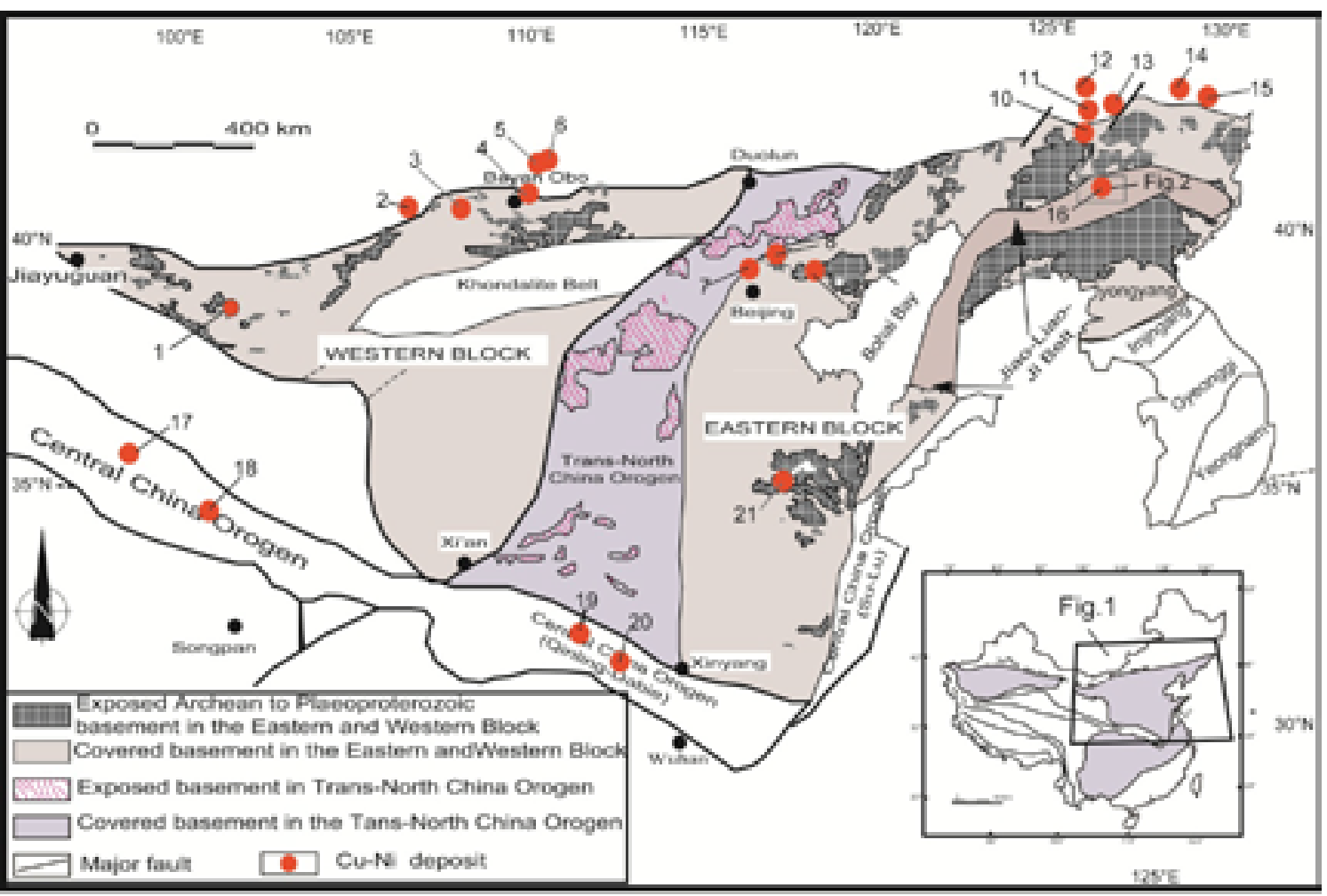

Cu-Ni deposits: $1=$ Jinchuan; 2=Ebutu; 3=Kebu; 4=Huanghuatan; $5=X$ Xiaonanshan; $6=$ Tunaobao; $7=$ Hongshiwan; $8=$ Hongshila; $9=$ Tongdongzi; $10=$ Chaluzi; $11=$ Jianchaling; 12=Sandaogang; 13=Hongqiling; 14=Piaohechuan; 15=Changren; 16=Chibaisong; 17=Yulonggou; 18=Lashuixia; 19=Jinpen; 20=Zhouan; $21=$ Hongdonggou.

Figure 1: Tectonic subdivision and major Cu-Ni deposit of the North China Craton [22].

$\mathrm{Cu}$ ore deposit are located in the Paleoproterozoic Jiao-Liao-Ji Belt in the Eastern Block of the NCC, which consists predominantly of Paleoproterozoic metamorphic basement rocks, overlain by Paleozoic and Mesozoic sedimentary cover (Figure 2). The Archean basement rocks are mainly composed of supracrutals (Anshan Group) and tonalitic-granodioritic gneisses metamorphosed in granulite- and amphibolite-facies, with minor two mica granite and hypersthene granite [27]. The Paleoproterozoic rocks are dominated by supracrustal rocks, named the Ji' an and Laoling Groups, and minor ultramafic, mafic and granitic intrusions and dykes [27].

\section{Local geology}

The host rocks of the Chibaisong $\mathrm{Cu}-\mathrm{Ni}$ deposit are metamorphic rocks of the Sidaolazi Formation of the Archean Anshan Group, which consists predominantly of biotite-amphibole-plagioclase gneiss, migmatite and amphibolite, all of which show strong ductile deformation (Figure3). The Chibaisong intrusions, extending $4800 \mathrm{~m}$ long along strike, with a width between 40 and $140 \mathrm{~m}$ (Figure 3), and a depth of $1000 \mathrm{~m}$ (Figure 4), are composed mainly of diabase gabbro, livinenorite-gabbro, plagioclase lherzolite, norite-gabbro and gabbroporphyrite [28]. The $\mathrm{Cu}-\mathrm{Ni}$ sulfide ores are hosted in the plagioclase lherzolite and norite-gabbro units. The orientation of the orebody is almost consistent with that of the intrusion, with its northern part striking $5-10^{\circ}$ and dips to the SEE at 55 to $86^{\circ}$, and its southern part dipping to the NWW at 63 to $85^{\circ}$ [28]. The orebody occurs as a tabular or bedlike unit, with a maximum length up to $200 \mathrm{~m}$ and a thickness of up to $40 \mathrm{~m}$ at the surface. The exploratory profile section reveals that the ore body extends as much as $1000 \mathrm{~m}$ down-dip.
Ore minerals are dominantly pyrrhotite, chalcopyrite, pentlandite, violarite, pyrite and magnetite. Associated noble metal-bearing minerals are melonite, michenerite, bitepalladite, sperrylite, hessite and electrum. Gangue minerals are mainly olivine, pyroxene, plagioclase, hornblende, biotite, chlorite and serpentinite.

Ore minerals are characterized by euhedral, subhedral, anhedral, subhedral-anhedral, porphyritic, corrosion, relict-replacement, reaction rim, pseudomorphic and skeletal crystal textures. Ore structures are mainly massive, vein, veinlet-disseminated, veinletmesh, or sparsely disseminated. The mineralization shows a circular zoning pattern, from high-grade massive ore in the center outwards to disseminated ores, gradually changing into sub-econonomic ores.

Wall-rock alteration related to mineralization in the Chibaisong $\mathrm{Cu}-\mathrm{Ni}$ deposit includes chloritization, sericitization, carbonatization, serpentinization. Characteristic minerals in the alteration zones are chlorite, serpentine, sericite and carbonate.

\section{Sampling andAnalytical Techniques}

\section{Sampling}

Sample collection: A fresh $40 \mathrm{~kg}$ olivine-norite-gabbro specimen used to obtain SHRIMP zircon U-Pb ages was collected in the eastern part of No.1 ore body, with coordinates of $125^{\circ} 42^{\prime} 38^{\prime \prime} \mathrm{E}, 41^{\circ} 40^{\prime} 07^{\prime \prime} \mathrm{N}$.

For Re-Os dating, we collected 6 samples from fresh open-pit mining faces of the Chibaisong deposit. Samples were collected at a depth of $300 \mathrm{~m}$ in the eastern part of ore body (Figure 3 ). 
Citation: Chun-Ming H, Fu-Yuan W, Wen-JiaoX, Guo-Chun Z, Song-Jian A, et al. (2014) The Paleoproterozoic Chibaisong Mafic-Ultramafic Intrusion and Cu-Ni Deposit, North China Craton: SHRIMP Zircon U-Pband Re-Os Geochronology and Geodynamic Implications. J Geophys Remote Sensing 3: 116. doi:10.4172/2169-0049.1000116

Page 3 of 8

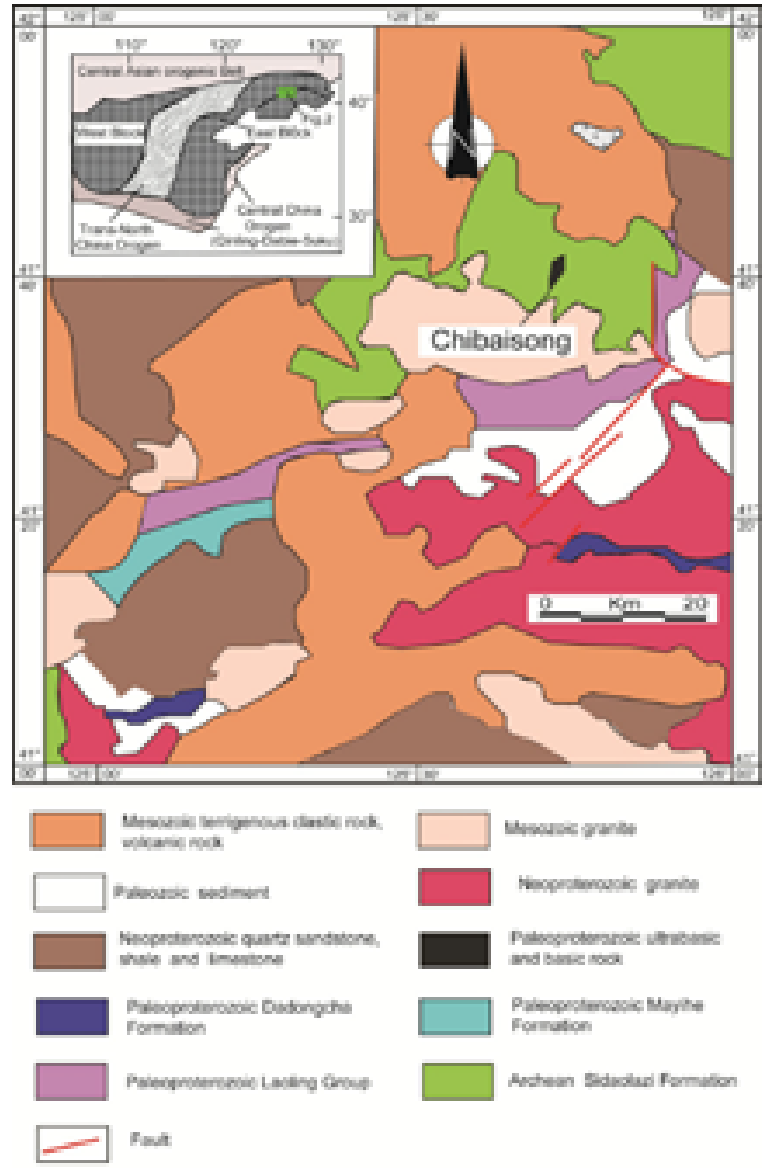

Figure 2: Geological map of the eastern part of Jilin province [27].

Sample selection: Zircon grains from sample Y041 were separated at the Laboratory of the Institute of Regional Geology and Mineral Resources Survey in Hebei Province. The gneiss sample was jawcrushed, split, and ground to $100 \mu \mathrm{m}$ using conventional methods, then primarily separated using electromagnetic and heavy liquid techniques. Finally, grains were handpicked according to their euhedral shapes and transparency, using a binocular microscope. Zircons were separated from the crushed samples using heavy liquids and a Frantz magnetic separator. Approximately 80 zircons from sample Y041 were handpicked, mounted in epoxy resin and polished until the grain centers were exposed.

Single sulfide grains were also selected at the above-mentioned laboratory. Crude ore samples were jaw-crushed, elutriated by water, separated by Frantz magnetic techniques, panned by alcohol, and finally hand sorted under the microscope. The weight of six pure pyrrhotite samples was about $5 \mathrm{~g}$ each. To avoid Re contamination from steel and tungsten carbide crushing equipment, the pure pyrrhotite powders from the Fujia deposit were pulverized to b200-mesh grain size using a ceramic jaw crusher and agate mill. The purity of the samples was greater than $99 \%$ prior to Re-Os isotopic analyses.

\section{Analytical procedures}

Cathodoluminescence (CL) images: The CL images were obtained using a CAMECA SX50 microprobe at the Institute of Geology and Geophysics, Chinese Academy of Sciences in Beijing, in order to identify internal textures and choose potential target sites for later $\mathrm{U}_{-}$ $\mathrm{Pb}$ analyses. The working conditions during $\mathrm{CL}$ imaging were at $15 \mathrm{kV}$.
SHRIMP U-Pb isotope analytical techniques: Zircon-U-Th$\mathrm{Pb}$ analyses were performed using the Sensitive High-Resolution Ion Microprobe (SHRIMP II) at the Beijing SHRIMP Laboratory, Chinese Academy of Geological Sciences. Details of the analytical methods and procedures for zircon dating using SHRIMP have been described by [29-32]. Analytical target sites within zircons were chosen for SHRIMP $\mathrm{U}-\mathrm{Pb}$ zircon dating. Due to small amounts of ${ }^{207} \mathrm{~Pb}$ formed in young (i.e., $\sim 1000 \mathrm{Ma}$ ) zircons, which results in low count rates and high analytical uncertainties, the determination of the ages for young zircons has to be based primarily on their ${ }^{206} \mathrm{~Pb} /{ }^{238} \mathrm{U}$ ratios; older zircon ages are derived from ${ }^{207} \mathrm{~Pb} /{ }^{206} \mathrm{~Pb}$ ratios [33]. During the SHRIMP analyses, the intensity of the preliminary ion current was $2.5-4.5 \mathrm{nA}$ and spot size averaged $25-30 \mu \mathrm{m}$, using peakjumpingscanningmode. The measured ${ }^{206} \mathrm{~Pb} /{ }^{238} \mathrm{U}$ ratios were used for inter-element fractionation corrections with TEMORA zircon standards $\left(417 \mathrm{Ma} ;{ }^{206} \mathrm{~Pb} /{ }^{238} \mathrm{U}=0.06683\right)$. The SL 13 zircon standard was used for calibration of $\mathrm{U}$, $\mathrm{Th}$ and $\mathrm{Pb}$ contents. Common lead corrections were based on measured ${ }^{204} \mathrm{~Pb}$ assuming that the ${ }^{206} \mathrm{~Pb} /{ }^{238} \mathrm{U}-206 \mathrm{~Pb} / 232 \mathrm{Th}$ age was accordant. The standard sample was measured after every three points, in order to insure the reliability of the measured results and then to monitor the stability of the instrument. The isotopic ratio and element content data were handled using ISOPLOT programs [34]. The age uncertainties are cited as $1 \sigma$, and the weighted average ages of ${ }^{206} \mathrm{~Pb} /{ }^{238} \mathrm{U}$ used have a confidence level $(2 \sigma)$ of $95 \%$.

\section{Re-Osisotope analytical technique}

Re-Os isotopic analyses were performed at the National Research

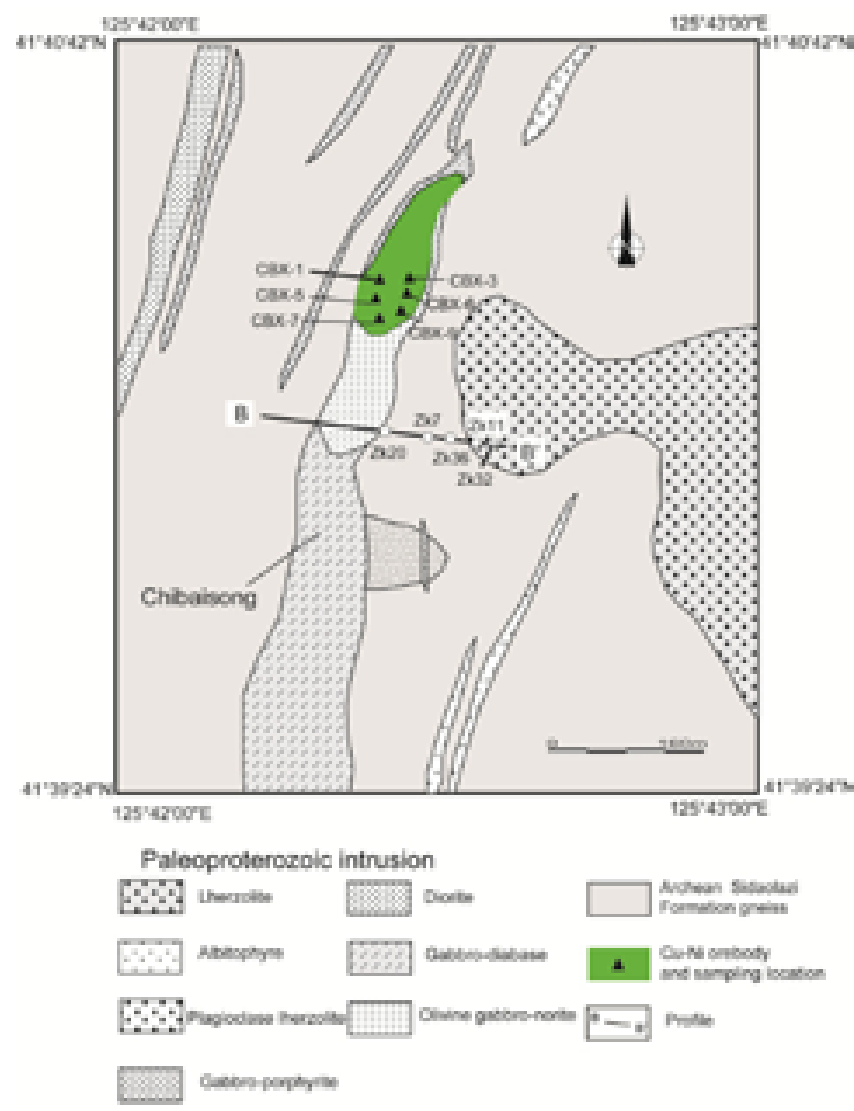

Figure 3: Geological and showing sampling locations map No. 1 ore body of the Chibaisong Cu-Ni deposit [28]. 
Citation: Chun-Ming H, Fu-Yuan W, Wen-JiaoX, Guo-Chun Z, Song-Jian A, et al. (2014) The Paleoproterozoic Chibaisong Mafic-Ultramafic Intrusion and Cu-Ni Deposit, North China Craton: SHRIMP Zircon U-Pband Re-Os Geochronology and Geodynamic Implications. J Geophys Remote Sensing 3: 116. doi:10.4172/2169-0049.1000116

Page 4 of 8

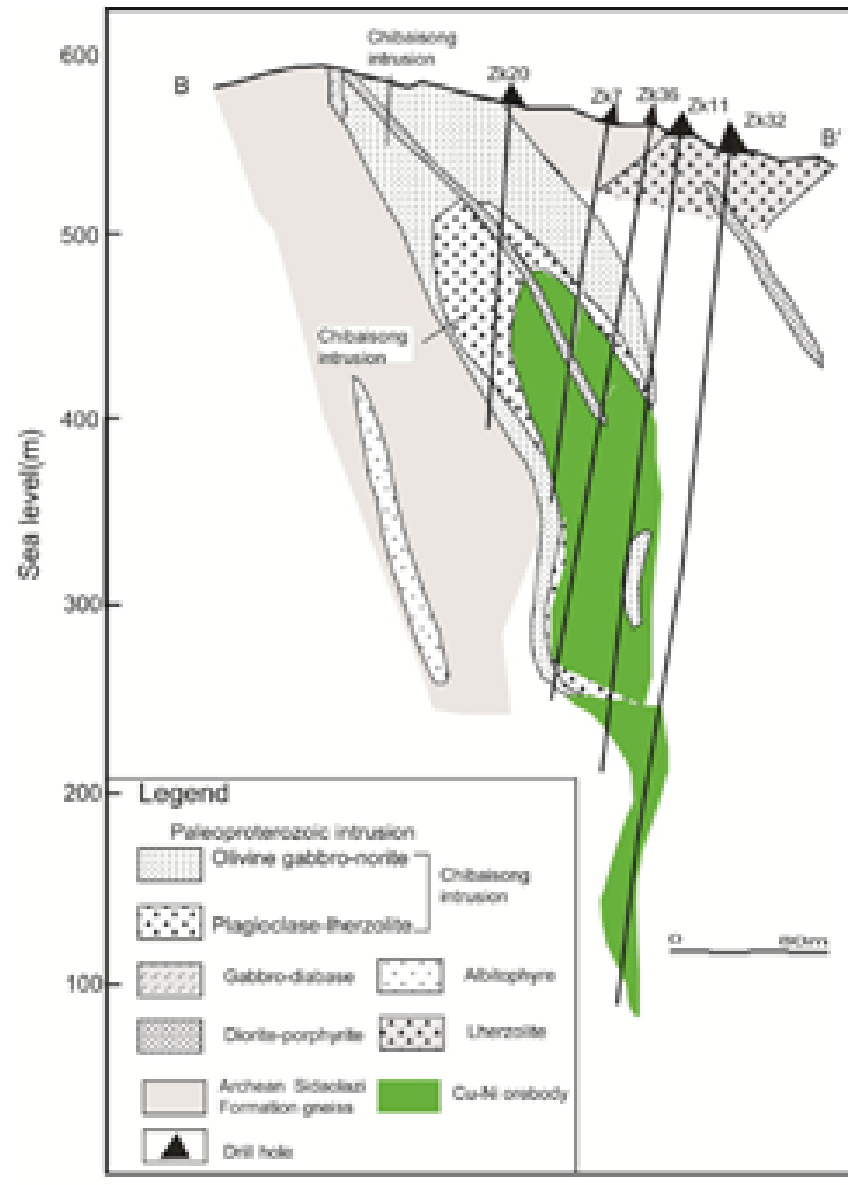

Figure 4: Geologic section of No. 1 intrusion at Chibaisong Cu-Ni deposit [28].

Center of Geoanalysis. The details of the chemical procedure are described by [35-37], and are briefly summarized as follows.

Enriched ${ }^{190} \mathrm{Os}$ and enriched ${ }^{185} \mathrm{Re}$ were obtained from the Oak Ridge National Laboratory, USA. A Carius tube (a thick-walled borosilicate glass ampoule) digestion was used. The weighed sample was loaded in the Carius tube through a thin necked long funnel. The mixed ${ }^{190} \mathrm{Os}$ and ${ }^{185} \mathrm{Re}$ spike solutions and $2 \mathrm{ml}$ of $12 \mathrm{M} \mathrm{HCl}$ and $6 \mathrm{ml}$ of $15 \mathrm{M} \mathrm{HNO}_{3}$ were loaded while the bottom part of the tube was frozen at $-80^{\circ} \mathrm{C}$ to $-50^{\circ} \mathrm{C}$ in an ethanol-liquid nitrogen slush; the top was then sealed using an oxygen-propane torch. The tube was then placed in a stainless-steel jacket and heated for 24 hours at $230^{\circ} \mathrm{C}$. Upon cooling, the bottom part of the tube was refrozen, the neck of the tube was broken, and the contents of the tube were poured into a distillation flask and the residue was washed out with $40 \mathrm{ml}$ of water.

Osmium was distilled at $105-110^{\circ} \mathrm{C}$ for 50 minutes and trapped in $10 \mathrm{ml}$ of water. The residual Re-bearing solution was saved in a $150 \mathrm{ml}$ Teflon beaker for late Re separation. The water trap solution was used for ICP-MS (TJA X-series) determination of the Os isotope ratio.

The Re-bearing solution was evaporated to dryness, and $1 \mathrm{ml}$ of water was added twice, followed by heating to near-dryness, the $10 \mathrm{ml}$ of $20 \% \mathrm{NaOH}$ was added to the residue followed by Re extraction with $10 \mathrm{ml}$ of acetone in a $120 \mathrm{ml}$ Teflon separation funnel. The water phase was then discarded and the acetone phase washed with $2 \mathrm{ml}$ of $20 \%$ $\mathrm{NaOH}$. The acetone phase was transferred to a $120 \mathrm{ml}$ Teflon beaker that contained $2 \mathrm{ml}$ of water. After evaporation to dryness, the Re was picked up in $1 \mathrm{ml}$ of water that was used for the ICP-MS determination of the Re isotope ratio. Cation-exchange resin was used to remove $\mathrm{Na}$ when the salinity of the Re-bearing solution was more than $1 \mathrm{mg} / \mathrm{ml}$ [38].

The ICP-MS analysis was conducted on a TJA PQ ExCELL ICP mass spectrometer. The instrument was optimized to: $>5 \times 10^{4} \mathrm{cps}$ for $1 \mathrm{ng} \mathrm{ml}-{ }^{1115} \mathrm{In}$ and $>5 \times 10^{4} \mathrm{cps}$ for $1 \mathrm{ng} \mathrm{ml}^{-1238} \mathrm{U}$. Data acquisition was performed in peak-jumping mode, 3 points $/ \mathrm{u}$; dwell time $=15 \mathrm{~ms} /$ point and number of scan $=200$ for $5 \mathrm{ppb}$ of Re in solution. The reproducibility by ICP-MS is $0.3 \%$ (RSD, $2 S, n=5$ ); by using water as an absorbent for $\mathrm{OsO}_{4}$, the sensitivity of Os by ICP-MS increases significantly. For 0.2 $\mathrm{ppb}$ of Os solution, the reproducibility is $0.3 \%$ (RSD, $2 \mathrm{~S}, \mathrm{n}=5$ ).

If a minor ${ }^{190} \mathrm{Os}$ signal was observed when measuring $\mathrm{Re}$, the ${ }^{187} \mathrm{Re}$ signal was appropriately corrected for ${ }^{187} \mathrm{Os}$ using the ${ }^{187} \mathrm{Os} /{ }^{190} \mathrm{Os}$ ratio of the spiked Os solution. Conversely, if a minor ${ }^{185}$ Re signal was observed while analyzing the Os-bearing solution, ${ }^{187} \mathrm{Os}$ was appropriately corrected for ${ }^{187} \mathrm{Re}$ using the measured ${ }^{185} \mathrm{Re} /{ }^{187} \mathrm{Re}$ of the spiked sample. The corrections were generally minor and constituted no more than $0.1 \%$ of the isotope signal. The maximum correction percentage that we used was always less than $1 \%$.

The mass fractionation can be corrected using an interlaboratory isotope reference standard. Using the $\lambda^{238} \mathrm{U}$ value of [39] and $\lambda^{235}$ value of [40], a value for $\lambda^{187} \mathrm{Re}$ of $1.6689 \pm 0.0031 \times 10^{-11} \mathrm{a}^{-1}$ was determined. This value is nominally higher (ca. $0.1 \%$ and ca. $0.2 \%$ ) than the value determined by [40], but is within the calculated uncertainty. So, we used the $\lambda^{187} \operatorname{Re} 1.666 \pm 0.005 \times 10^{-11} \mathrm{a}^{-1}$ determined by [40].

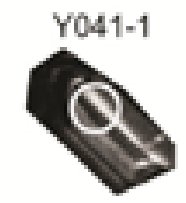

$2178 \pm 7 \mathrm{Ma}$

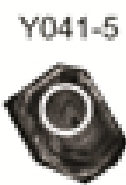

$2002 \pm 8 \mathrm{Ma}$

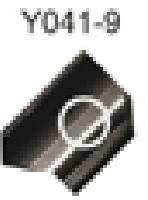

$2200 \pm 4 \mathrm{Me}$

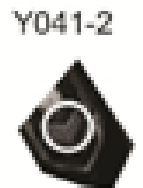

$2191 \pm 5 \mathrm{Ma}$

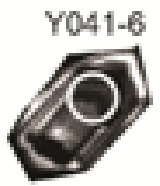

$2184 \pm 6 \mathrm{Ma}$

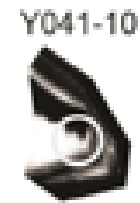

$2186 \pm 7 \mathrm{Ma}$

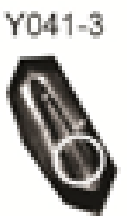

$2232 \pm 37 \mathrm{Ma}$

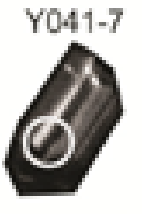

$2195 \pm 6 \mathrm{Ma}$

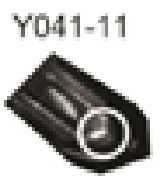

$2189 \pm 6 \mathrm{Ma}$

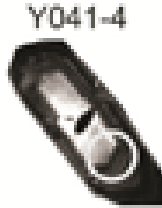

$2056 \pm 9 \mathrm{Ma}$
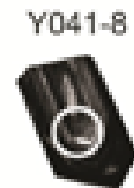

$2173 \pm 11 \mathrm{Ma}$

Y041-12

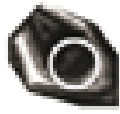

$2175 \pm 4 \mathrm{Ma}$

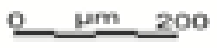

Figure 5: $\mathrm{CL}$ images, localities of SHRIMP measurement spots and ${ }^{206} \mathrm{~Pb} / 238 \mathrm{U}$ apparent ages of zircons from olivine-norite-gabbro of the Chibaisong intrusion in eastern Jilin, NE China. 
Citation: Chun-Ming H, Fu-Yuan W, Wen-JiaoX, Guo-Chun Z, Song-Jian A, et al. (2014) The Paleoproterozoic Chibaisong Mafic-Ultramafic Intrusion and Cu-Ni Deposit, North China Craton: SHRIMP Zircon U-Pband Re-Os Geochronology and Geodynamic Implications. J Geophys Remote Sensing 3: 116. doi:10.4172/2169-0049.1000116

Page 5 of 8

Average blanks for the total Carius tube procedure as described above were ca. $10 \mathrm{pg}$ Re and ca. 0.1 pgOs. ${ }^{187}$ Os was not detected. Three reference materials were used to check the analytical results.

The uncertainty in each individual age determination was about $1.02 \%$ including the uncertainty of the decay constant of ${ }^{187} \mathrm{Re}$, uncertainty in isotope ratio measurement, and spike calibrations. The decay constant used for ${ }^{187} \mathrm{Re}$ of $1.666 \times 10^{-11} \mathrm{a}^{-1}$ has an absolute uncertainty of $\pm 0.017(1.0 \%)[40]$

\section{Results}

\section{SHRIMP U-Pb dating results}

Twelve analyses of 12 grains from Chibaisong olivine-noritegabbro were analyzed on the CZ3 standard (Figure 5). Of these analyses (Table 1), two age populations are identified (Figure 6), of which one population consists of eight grains gave a $\mathrm{Th} / \mathrm{U}$ ratio larger than 4.0, indicating an igneous origin, and yield ${ }^{207} \mathrm{~Pb} /{ }^{206} \mathrm{~Pb}$ weighted average age of $2188 \pm 8 \mathrm{Ma}$, which is considered as the best estimate of the eruption age of this rock. Another age group consists of four grains with $\mathrm{Th} / \mathrm{U}$ ratios of less than 1.0 , these zircons have Th and $\mathrm{U}$ contents and $\mathrm{Th} / \mathrm{U}$ ratios ranging respectively from 84 to $393 \mathrm{ppm}, 175$ to 823 ppm and 0.33 to 0.48 , which are different from typical metamorphic zircons and are thus regarded to be detrital zircons that suffered variable $\mathrm{Pb}$ loss in metamorphism. Thus, the concordant age of 2188

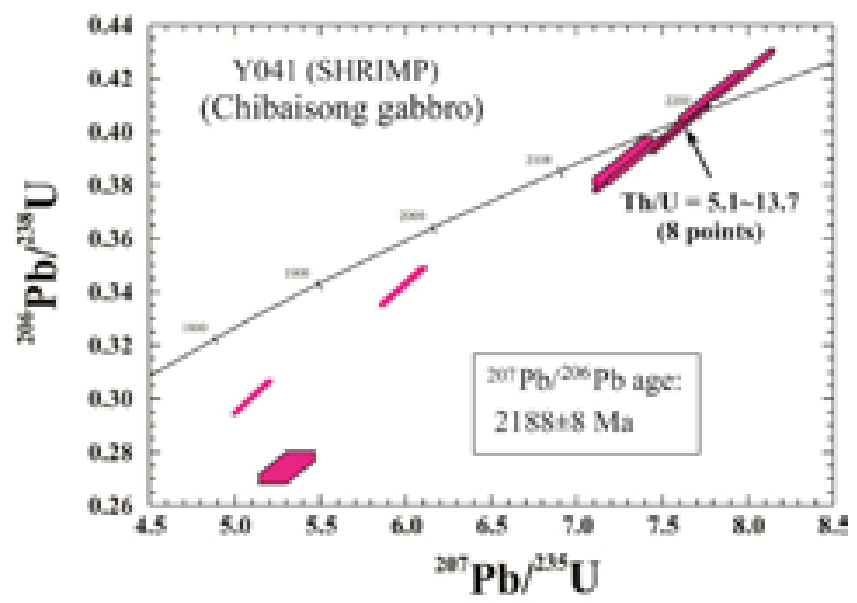

Figure 6: Zircon SHRIMP U-Pbconcordia diagram of olivine-norite-gabbro from the Chibaisong intrusion. \pm 8 Ma may be the best constraint for estimating the maximum age of the Chibaisong deposit.

\section{Re-Os dating results}

The abundance of Re and Os and the osmium isotopic compositions of the $\mathrm{Cu}-\mathrm{Ni}$ sulfide ores from the Chibaisong mine are shown in Table 2. Re and Os concentrations for the massive sulfide of the Chibaisong deposit are high, ranging from 0.47 to $13.97 \mathrm{ppb}$ Os and 19 to $490 \mathrm{ppb}$ $\mathrm{Re}$ (Table 2). The analyses on six samples define a Re-Os isochron with an age of $1885 \pm 94 \mathrm{Ma}$, with initial ${ }^{187} \mathrm{Re} /{ }^{188} \mathrm{Os}$ ratio of $0.80 \pm 0.16$ and a mean square of weighted deviation (MSWD) of 0.17 (Figure7). The isochron age was calculated by means of the ${ }^{187} \mathrm{Re}$ decay constant of $1.666 \times 10^{-11} /$ year [40] using the ISOPLOT software (Model 3; [34]). This isochron age can reflect the ore-forming age of the Chibaisong $\mathrm{Cu}-\mathrm{Ni}$ deposit. The combination of high Os concentrations coupled with low Re/Os ratios is not typical of most low-tenor, basalt hosted magmatic sulfides (e.g. Duluth Complex), which exhibit much lower Os concentrations, coupled with higher Re/Os ratios [41]. This suggests a parental magma for the Chibaisong sulfides that had both a higher Os concentration and a lower Re/Os ratio than a typical basaltic magma.

\section{Discussion}

\section{Initial ${ }^{187} \mathrm{Os} /{ }^{188} \mathrm{Os}$ and source of ore-forming metals}

The Re-Os isotope system has been recognized as a geochemical tool not only for directly dating mineralization but also for defining the ore forming process of $\mathrm{Cu}-\mathrm{Ni}$ sulfide deposits, and thus is a powerful tracer of sulfide ore formation and can be a highly sensitive monitor of the extent of crustal involvement during ore genesis [42,43]. Since the initial ${ }^{187} \mathrm{Os} /{ }^{188} \mathrm{Os}$ ratios of the crust $(0.2-10)$ are higher than those of the mantle $(0.11-0.15,[44]),{ }^{187} \mathrm{Os} /{ }^{188} \mathrm{Os}$ ratios can be used to readily discern different sources [45].

The Chibaisong $\mathrm{Cu}-\mathrm{Ni}$ sulfides ores possess an initial ${ }^{187} \mathrm{Os} /{ }^{188} \mathrm{Os}$ ratio of $0.80 \pm 0.16$ (Figure 7), which is considerably greater than chondritic or value those of the mantle ${ }^{187} \mathrm{Os} /{ }^{188} \mathrm{Os}$ ratio at $1885 \mathrm{Ma}$ $[35,46,47]$, indicating that crustal components were involved in the Os source of the Chibaisong ores.

In order to describe the Os isotopic composition at a given time, a parameter of $\gamma_{\mathrm{Os}}$ was introduced by [46-48].

$$
\left.\left.\gamma_{\mathrm{Os}}(\mathrm{T})=100\left[{ }^{187} \mathrm{Os} /{ }^{186} \mathrm{Os}\right]_{\text {sample }}(\mathrm{T}) /{ }^{187} \mathrm{Os} /{ }^{186} \mathrm{Os}\right]_{\text {chondrite }}(\mathrm{T})-1\right] \text {. }
$$

Owing to high Re/Os ratios in the crust, $\gamma \mathrm{O}$ s will have a large positive value with increasing crustal material entering the magmatic or ore-forming systems, and, by contrast, Re-loss in the systems can cause

\begin{tabular}{|c|c|c|c|c|c|c|c|c|c|}
\hline \multirow[t]{2}{*}{ Spot } & \multirow[t]{2}{*}{$U(\mu g / g)$} & \multirow[t]{2}{*}{ Th $(\mu g / g)$} & \multirow[t]{2}{*}{$\mathrm{Pb}(\mu \mathrm{g} / \mathrm{g})$} & \multirow[t]{2}{*}{$\mathrm{Th} / \mathrm{U}$} & \multicolumn{3}{|c|}{ Isotopic ratios } & \multicolumn{2}{|c|}{ Age (Ma) } \\
\hline & & & & & ${ }^{207} \mathrm{~Pb} /{ }^{206} \mathrm{~Pb}$ & ${ }^{207} \mathrm{~Pb} /{ }^{235} \mathrm{U}$ & ${ }^{206} \mathrm{~Pb} /{ }^{238} \mathrm{U}$ & ${ }^{206} \mathrm{~Pb} /{ }^{238} \mathrm{U}$ & ${ }^{207} \mathrm{~Pb} /{ }^{235} \mathrm{U}$ \\
\hline Y041-1 & 411.80 & 2797.9 & 142.53 & 6.79 & $0.1361 \pm 05$ & $7.554 \pm 173$ & $0.4025 \pm 91$ & $2181 \pm 42$ & $2178 \pm 07$ \\
\hline Y041-2 & 864.48 & 4227.2 & 300.92 & 4.89 & $0.1371 \pm 04$ & $7.655 \pm 174$ & $0.4050 \pm 91$ & $2192 \pm 42$ & $2191 \pm 05$ \\
\hline Y041-3 & 823.65 & 393.17 & 194.20 & 0.48 & $0.1404 \pm 30$ & $5.306 \pm 165$ & $0.2741 \pm 62$ & $1561 \pm 31$ & $2232 \pm 37$ \\
\hline Y041-4 & 397.54 & 132.28 & 116.95 & 0.33 & $0.1269 \pm 06$ & $5.990 \pm 140$ & $0.3423 \pm 78$ & $1898 \pm 37$ & $2056 \pm 09$ \\
\hline Y041-5 & 562.49 & 230.91 & 145.42 & 0.41 & $0.1231 \pm 06$ & $5.101 \pm 117$ & $0.3005 \pm 68$ & $1694 \pm 34$ & $2002 \pm 08$ \\
\hline Y041-6 & 692.64 & 4968.8 & 229.77 & 7.17 & $0.1366 \pm 05$ & $7.270 \pm 167$ & $0.3861 \pm 88$ & $2105 \pm 41$ & $2184 \pm 06$ \\
\hline Y041-7 & 410.28 & 2135.6 & 148.54 & 5.21 & $0.1375 \pm 05$ & $7.985 \pm 183$ & $0.4213 \pm 95$ & $2267 \pm 43$ & $2195 \pm 06$ \\
\hline Y041-8 & 175.92 & 84.52 & 58.84 & 0.48 & $0.1357 \pm 09$ & $7.280 \pm 174$ & $0.3891 \pm 90$ & $2119 \pm 42$ & $2173 \pm 11$ \\
\hline Y041-9 & 1025.2 & 8095.2 & 353.31 & 7.90 & $0.1378 \pm 03$ & $7.623 \pm 172$ & $0.4011 \pm 90$ & $2174 \pm 41$ & $2200 \pm 04$ \\
\hline Y041-10 & 348.38 & 2169.1 & 123.73 & 6.23 & $0.1367 \pm 06$ & $7.789 \pm 180$ & $0.4133 \pm 94$ & $2230 \pm 43$ & $2186 \pm 07$ \\
\hline Y041-11 & 746.13 & 7474.5 & 249.67 & 10.0 & $0.1369 \pm 05$ & $7.351 \pm 167$ & $0.3894 \pm 88$ & $2120 \pm 41$ & $2189 \pm 06$ \\
\hline Y041-12 & 1126.3 & 14884 & 395.32 & 13.2 & $0.1359 \pm 03$ & $7.652 \pm 173$ & $0.4085 \pm 92$ & $2208 \pm 42$ & $2175 \pm 04$ \\
\hline
\end{tabular}

Table 1: SHRIMP zircon U-Pb analytical data of olivine-norite-gabbro from the Chibaisong intrusions. 
Citation: Chun-Ming H, Fu-Yuan W, Wen-JiaoX, Guo-Chun Z, Song-Jian A, et al. (2014) The Paleoproterozoic Chibaisong Mafic-Ultramafic Intrusion and Cu-Ni Deposit, North China Craton: SHRIMP Zircon U-Pband Re-Os Geochronology and Geodynamic Implications. J Geophys Remote Sensing 3: 116. doi:10.4172/2169-0049.1000116

Page 6 of 8

\begin{tabular}{|c|c|c|c|c|c|c|c|c|c|}
\hline Sample & $\begin{array}{c}\text { Sample } \\
\text { weight (g) }\end{array}$ & $\begin{array}{c}\operatorname{Re}(p p b) \\
(2 \sigma)^{\mathrm{a}}\end{array}$ & $\begin{array}{c}\text { Common Os } \\
(\mathrm{ppb})(2 \sigma)^{\mathrm{a}}\end{array}$ & $\begin{array}{c}{ }^{187} \mathrm{Os} \mathrm{(ppb)} \\
(2 \sigma)\end{array}$ & $\mathrm{Re} / \mathrm{Os}$ & ${ }^{187} \mathrm{Re} /{ }^{188} \mathrm{Os}(2 \sigma)$ & $\begin{array}{c}{ }^{187} \mathrm{Os} /{ }^{188} \text { Os } \\
(2 \sigma)^{\mathrm{b}}\end{array}$ & $\begin{array}{l}{ }^{187} \mathrm{Os} /{ }^{188} \mathrm{Os} \\
\text { (i) }\end{array}$ & $\gamma_{\text {os }}$ \\
\hline CBX-1 & 0.300 & $19.27(0.15)$ & $0.81(0.01)$ & $0.47(0.01)$ & 23.70 & $114.5(1.4)$ & $4.458(0.041)$ & 0.21 & 87.34 \\
\hline CBX-3 & 0.300 & $302.1(2.3)$ & $48.84(7.40)$ & $11.24(1.67)$ & 6.19 & $29.87(4.53)$ & $1.768(0.375)$ & 0.66 & 488.78 \\
\hline CBX-5 & 0.300 & $490.2(5.5)$ & $44.31(5.87)$ & $13.97(1.81)$ & 11.06 & $53.43(7.10)$ & $2.422(0.448)$ & 0.44 & 292.52 \\
\hline CBX-6 & 0.300 & $234.7(2.1)$ & $14.75(1.06)$ & $6.191(0.416)$ & 15.91 & $76.86(5.54)$ & $3.226(0.315)$ & 0.37 & 230.07 \\
\hline CBX-7 & 0.300 & $156.6(1.2)$ & $19.30(1.57)$ & $4.977(0.386)$ & 8.11 & $39.18(3.2)$ & $1.982(0.222)$ & 0.53 & 372.81 \\
\hline CBX-9 & 0.300 & $147.5(2.1)$ & $19.72(0.91)$ & $5.102(0.228)$ & 7.48 & $36.20(1.70)$ & $1.989(0.126)$ & 0.65 & 479.86 \\
\hline
\end{tabular}

(1) Os in Re/Os is common Os. Common Os and common ${ }^{187} \mathrm{Os}$ are calculated according to the Nier value.

(2) The calculation formula is $\gamma_{\mathrm{os}}=100\left[\left({ }^{187} \mathrm{Os} /{ }^{188} \mathrm{Os}\right)\right.$ sample $(\mathrm{T}) /\left({ }^{187} \mathrm{Os} /{ }^{188} \mathrm{Os}\right)$ chondrite $\left.(\mathrm{T})-1\right]$, where $\left({ }^{187} \mathrm{Os} /{ }^{188} \mathrm{Os}\right)$ chondrite $=0.09531+0.40186\left(\mathrm{e}^{\lambda \mathrm{Re} * 4.558 \mathrm{E}}\right.$ - $\left.\mathrm{e}^{\lambda \mathrm{Re} * \mathrm{t}}\right)=0.1120953$ at $2188 \mathrm{Ma}$, using the $187 \mathrm{Re}$ decay constant $\lambda=1.666 \times 10^{-11} /$ year;

${ }^{a} \mathrm{Re}$ and Os uncertainty $<1 \%$ at 2 standard errors of the mean, including error samples and spike weighting, spike calibration, mass spectrometric analysis, fractionation correction and measured isotope ratios in the samples.

${ }^{\mathrm{b} 187} \mathrm{Os} /{ }^{188} \mathrm{Os}$ uncertainty $<1 \%$ at 2 standard errors of the mean, including error in mass spectrographic analysis, fractionation correction and measured isotope ratios in the samples.

Table 2: Re-Os isotope data for the Cu-Ni sulfide ores from the Chibaisong deposit.

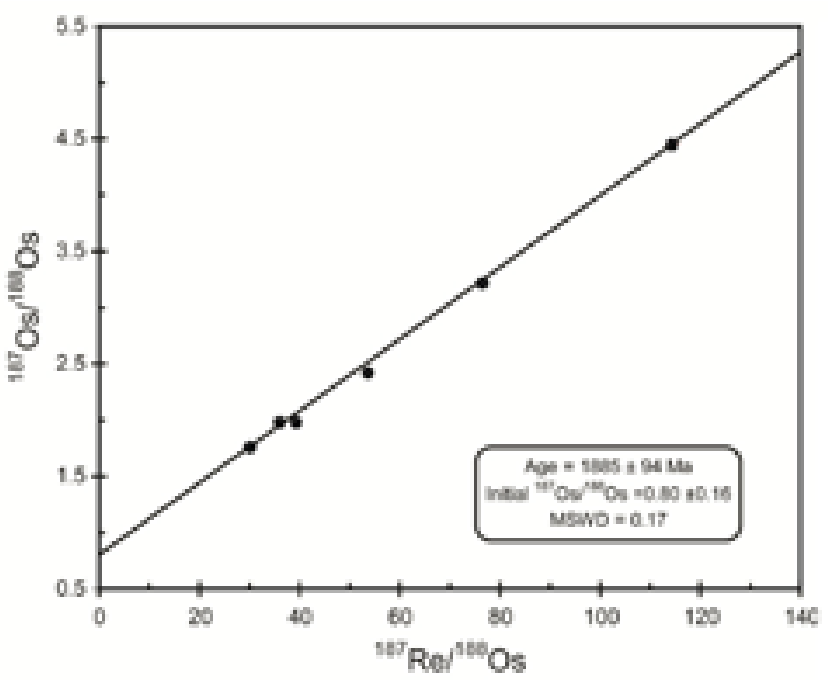

Figure 7: Re-Osisochron of the $\mathrm{Cu}-\mathrm{Ni}$ sulfide ores of the Chibaisong deposit, northeastern China.

negative $\gamma_{\mathrm{OS}}$ [49]. According to the formula of [48], and with a decay constant of $1.666 \times 10^{-11} /$ year [40], the $\gamma_{\mathrm{Os}}$ values for the Chibaisong $\mathrm{Cu}$ Ni sulfide ores were calculated based on the isochron age of $1885 \pm 94 \mathrm{Ma}$ and their corresponding initial ${ }^{187} \mathrm{Os} /{ }^{188} \mathrm{Os}$ ratios. Table 2 shows that the $\gamma_{\mathrm{OS}}$ values for the Chibaisong $\mathrm{Cu}-\mathrm{Ni}$ sulfide ores range from 87 to 488 . The initial ${ }^{187} \mathrm{Os} /{ }^{188} \mathrm{Os}$ ratio of $0.80 \pm 0.16$ for the Chibaisong sulfides is higher than that of $0.1089 \pm 0.00035$ reported for the uncontaminated Archeankomatite-related $\mathrm{Cu}-\mathrm{Ni}$ sulfide ores [50]. These data reflect that mafic-ultramafic magmas were mixed with crustal components during the uprised of the magma or within magma chambers in the crust. This process is analogous to the crustal contamination of the Voisey's Bay magma by the Tasiuyakparagneiss where siderophile and chalcophile elements were selectively incorporated and the case of the Jinbulake intrusion in Xinjiang where crustal sulfides were selectively incorporated to magmas [51]. Such features can also be seen in the common Os vs. Re/Os diagram (Figure 8).

$\mathrm{Fu}$ [52] reported the $\delta^{34} \mathrm{~S}$ values of sulfides from the Chibaisong ore body range from -1.1 to $+0.7 \%$, with a mean of $-0.03 \%$, and $\delta^{18} \mathrm{O}$ values of plagioclase from the Chibaisong intrusion range from +6.1 to $+7.7 \%$, with a mean of $+7.15 \%$ [ [52]. The initial ${ }^{87} \mathrm{Sr} /{ }^{86} \mathrm{Sr}$ ratios of the intrusions vary from 0.703 to 0.708 [52]. These data support the hypothesis that the ore-forming metals were derived mainly from a mantle source and the crust was not a major contributor of volatiles.

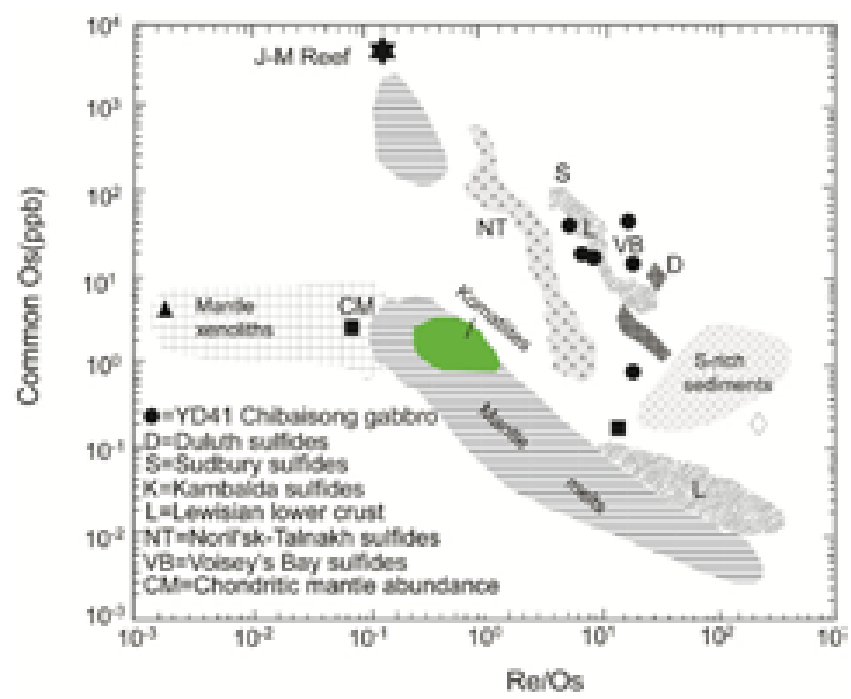

Figure 8: Common Os concentration (Os concentration at the time of ore formation) vs. Re/Os, showing data for a PGE-rich sulfide concentrate from the J-M reef, Lower Banded series and basalt associated $\mathrm{Cu}-\mathrm{Ni}$ sulfide ores from the basal and lower ultramafic series, Stillwater Complex [56]; Duluth Complex [57], Sudbury [58], and Noril'sk-Talnakh [46]; Komatiite-associated $\mathrm{Ni}$ sulfide ores from Kambalda [42]; Archean lithospheric mantle xenoliths from the Kaapvaal and Siberian Cratons [48]; mantle melts, which include komatiites [42,49] and basalts [60-62]; Lewisian lower crustal gneisses; metalliferous S-rich sediments; and chondritic mantle abundances [48].

This implies that ores and melts at the Chibaisong deposit were all dominated by mantle sources, although some minor amount of crustal material may have been assimilated into the melts.

\section{Age of mineralization and its geodynamic significance}

The Chibaisong intrusion was previously considered to have been linked to a post-orogenic extensional setting in the Early Cretaceous [5]. However, our new SHRIMP and Re-Os geochronological results indicate that the Chibaisong mafic-ultramafic intrusion, along with the $\mathrm{Cu}-\mathrm{Ni}$ deposit, was probably related to the Paleoproterozoic mantle plumes or superplume, rather than in the Early Cretaceous postorogenic extension setting.

This new SHRIMP and Re-Os age $(1885 \pm 94 \mathrm{Ma})$ for sulfide mineralisation at the base of the Chibaisong intrusion is marginally younger than the previously determined ages of the nearby Chibaisong intrusion $(2188 \pm 8 \mathrm{Ma})$. Working on the geochronology of dyke swarms in the NCC, Peng et al. [53] identified four dyke suites with SHRIMP 
Citation: Chun-Ming H, Fu-Yuan W, Wen-JiaoX, Guo-Chun Z, Song-Jian A, et al. (2014) The Paleoproterozoic Chibaisong Mafic-Ultramafic Intrusion and Cu-Ni Deposit, North China Craton: SHRIMP Zircon U-Pband Re-Os Geochronology and Geodynamic Implications. J Geophys Remote Sensing 3: 116. doi:10.4172/2169-0049.1000116

U-Pb ages of $2147 \pm 5,1929 \pm 8,1834 \pm 5$ and $1778 \pm 3 \mathrm{Ma}$. On the basis of this geochronology [52], Peng et al. [53] suggested that the older group of dyke suites could have been related to the amalgamation of the NCC to the Columbia supercontinent, whereas the younger suites were related to the breakup of Columbia and a mantle plume event at 2147-1778 $\mathrm{Ma}$ [52]. Mafic dykes in the Chibaisong region, have SHRIMP U-Pb and LA-ICP-MS ages of $2188 \pm 8$ and $2145 \pm 19 \mathrm{Ma}$, respectively, confirming the Paleoproterozoic rifting processes within the NCC. The Chibaisong ultramafic-mafic intrusion was located within the Paleoproterozoic Jiao-Liao-Ji Belt which is considered as an intercontinental rift zone that developed about $2.2 \mathrm{Ga}$ and the rifting basin was closed at about 1.93-1.90 Ga, followed by a post-orogenic extensional event at 1.88-1.85 Ga [15-17,53,54]. The Chibaisong ultramafic-mafic intrusion was likely the earliest product of this postorogenic extensional event.

\section{Conclusions}

i. Zircon SHRIMP U-Pb ages of the Chibaisongmagmatic $\mathrm{Ni}-\mathrm{Cu}$ sulfide deposits indicate a maximum depositional age of $2188 \pm 8 \mathrm{Ma}$. This result is consistent with the geological fact that ore-bearing maficultramafic intrusions intruded into the Sidaolazi Formation of the Anshan Group.

ii. Six massive $\mathrm{Ni}-\mathrm{Cu}$ sulfide ores of the Chibaisong deposit yielded a Re-Os isotopic isochron age of $1885 \pm 94 \mathrm{Ma}$, indicating that the oreforming age was Paleoproterozoic.

iii. Massive Ni-Cu sulfide ores of initial ${ }^{187} \mathrm{Re} /{ }^{188} \mathrm{Os}$ ratio of $0.80 \pm$ 0.16 , and their $\gamma \mathrm{Os}$ values ranged from +24 to +622 , indicating that ore-forming materials came mainly from the mantle with crustal Os contamination, suggesting a mixture of mantle and crustal sources.

iv. The Chibaisong $\mathrm{Cu}-\mathrm{Ni}$ deposit was located within the Paleoproterozoic Jiao-Liao-Ji Belt which was the earliest product of the post-orogenic extensional event.

\section{Acknowledgements}

We are indebted to Bin Cui, Kezhang Qin, Lianchang Zhang,Zhiliang Wang and Jianming Yang for thoughtful discussions. Many of the ideas in this paper were initiated and rectified during these discussions. We are grateful to SA Wilde and BF Windley for their constructive discussions and comments on an early version of the manuscript, which led to substantial improvements to the paper.This study was financially supported by the Chinese National Basic Research 973 Program (2012CB416604, 2014CB448000), the National Natural Science Foundation of China (41390445, 41230207, 41390441, 41190075, 41272107,40933036 and 41202150), the One Hundred Talent Program B of the Chinese Academy of Sciences, the Chinese National Basic Research 973 Program (2007CB411307), and the National 305 Projects (2011BAB06B04 and 2007BAB25B04). B. Wan wishes to thank the Visiting Scholar Program of the Chinese Academy of Sciences. This is a contribution to IGCP 592.

\section{References}

1. Kerrich R, Goldfarb RJ, Richards J (2005) Metallogenic provinces in an evolving geodynamic framework. Economic Geology 100: 1097-1136.

2. Tang ZL, Yang JD (1992) Jinchuan ore-bearing ultramafic rocks of the Sm-Nd dating. Chinese Science Bulletin 37: 918-920.

3. Li XH, Shu L, Chung SL, Li ZX, LiuY, et al. (2005) Formation of the Jinchuan ultramafic intrusion and the world's third largest $\mathrm{Ni}-\mathrm{Cu}$ deposit: Associated with the $\sim 825 \mathrm{Ma}$ south China mantle plume. Geochemistry Geophysics Geosystems 6 .

4. Zhang ZQ, Du AD, Tang SH, Lu JR, Wang JH, et al. (2004) Age of the Jinchuan copper-nickel deposit and isotopic geochemical feature of its source. Acta Geologica Sinica 78: 358-365.

5. Pei FP, Xu WL, Yang DB, Zhao QG (2005) SHRIMP zircon U-Pb dating and its geological significance of Chibaisong gabbro in Tonghua area, Jilin Province. Science of China 49: 368-374.
6. Sengör AMC, Natal'in BA, Burtman VS (1993) Evolution of the Altaids collage and Paleozoic crustal growth in Eurasia. Nature 364: 299-307.

7. Xiao WJ, Windley BF, Hao J, Zhai MG (2003) Accretion leading to collision and the Permian Solonkersuture, Inner Mongolia, China: termination of the central Asian orogenic belt. Tectonics 22: 1069.

8. Li SG, Xiao Y, Liou D, Chen Y, Ge N, et al. (1993) Collision of the North China and Yangtse Blocks and formation of coesite-bearing eclogites: timing and processes. Chemical Geology 109: 89-111.

9. Meng QR, Zhang GW (2000) Geologic framework and tectonic evolution of the Qinling orogen, central China. Tectonophysics 323: 183-196.

10. Windley BF, Alexeiev D, Xiao WJ, Kröner A, Badarch G (2007) Tectonic models for accretion of the Central Asian Orogenic Belt. J Geol Soc London 164: 31-47.

11. Zhao GC, Sun M, Wilde SA, Li SZ (2005) Late Archean to Paleoproterozoic evolution of the North China Craton: key issues revisited. Precambrian Research 136: 177-202.

12. Xia XP, Sun M, Zhao GC, Wu FY, Xu P, et al. (2008) Paleoproterozoic crustal growth events in the Western Block of the North China Craton: Evidence from detrital zircon $\mathrm{Hf}$ and whole rock $\mathrm{Sr}-\mathrm{Nd}$ isotopes of the khondalites in the Jining Complex. Am J Sci 308: 304-327.

13. Yin CQ, Zhao GC, Sun M, Xia XP, Wei CJ, et al. (2009) LA-ICP-MS U-Pb zircon ages of the Qianlishan Complex: constrains on the evolution of the Khondalite Belt in the Western Block of the North China Craton. Precambrian Res 174 $78-94$

14. Yin $C Q$, Zhao GC, Guo JH, Sun M, Xia XP, et al. (2011) U-Pb and Hf isotopic study of zircons of the Helanshan Complex: constrains on the evolution of the Khondalite Belt in the Western Block of the North China Craton. Lithos 122 $25-38$.

15. Li SZ, Zhao GC, Sun M, Wu FY, Liu JZ, et al. (2004) Mesozoic, not Paleoproterozoic SHRIMP U-Pb zircon ages of two Liaoji Granites, Eastern Block, North China Craton. International Geology Review 46: 162-176.

16. Li SZ, Zhao GC, Santosh M, Liu X, Dai LM, et al. (2012) Paleoproterozoic structural evolution of the southern segment of the Jiao-Li Ji Belt, North China Craton. Precambrian Res 200-203: 59-73.

17. Li SZ, Zhao GC (2007) SHRIMP U-Pb zircon geochronology of the Liaoji granitoids: constraints on the evolution of the Paleoproterozoic Jiao-Liao-Ji belt in the Eastern Block of the North China Craton. Precambrian Res 158: 1-16.

18. Zhou XW, Zhao GC, Wei CJ, Geng YS, Sun M (2008) Metamorphic evolution and $\mathrm{Th}-\mathrm{U}-\mathrm{Pb}$ zircon and monazite geochronology of high-pressure pelitic granulites in the Jiaobei massif of the North China Craton. Am J Sci 308: 328350.

19. Tam PY, Zhao GC, Sun M, Li SZ, lizukac Y, et al (2012) Metamorphic P-T path and tectonic implications of medium-pressure pelitic granulites from the Jiaobei massif in the Jiao-Liao-Ji Belt, North China Craton. Precambrian Res 220-221: 177-191.

20. Tam PY, Zhao GC, Zhou XW, Sun M, Li SZ, et al. (2012) Metamorphic P-T path and implications of high-pressure pelitic granulites from the Jiaobei massif in the Jiao-Liao-Ji Belt, North China Craton. Gondwana Res 22: 104-117.

21. Tam PY, Zhao GC, Sun M, Li SZ, Wu ML, et al. (2012) Petrology and metamorphic P-T path of high-pressure mafic granulites from the Jiaobe massif in the Jiao-Liao-Ji Belt, North China Craton. Lithos 155: 94-109.

22. Zhao GC, Wilde SA, Cawood PA, Sun M (2001) Archean blocks and their boundaries in the North China Craton: lithological, geochemical, structural and P-T path constraints and tectonic evolution. Precambrian Res 107: 45-73.

23. Zhao GC, Wilde SA, Guo JH, Cawood PA, Sun M, et al. (2010) Single zircon grains record two continental collisional events in the North China craton. Precambrian Res 177: 266-276.

24. Zhao GC, Cawood PA, Wilde SA, Sun M, Zhang J, et al. (2012) Amalgamation of the North China Craton: key issues and discussion. Precambrian Res 222 223: 55-76.

25. Li SZ, Zhao GC, Wilde SA, Zhang J, Sun M, et al. (2010) Deformation history of the Hengshan-Wutai-Fuping Complexes: Implications for the evolution of the Trans-North China Orogen. Gondwana Res 18: 611-631.

26. Li XP, Yang ZY, Zhao GC, Grapes R, Guo JH (2011) Geochronology of khondaliteseries rocks of the Jining Complex: confirmation of depositional age and tectonometamorphic evolution of the North China craton. Int Geol Rev 53 1194-1211. 
Citation: Chun-Ming H, Fu-Yuan W, Wen-JiaoX, Guo-Chun Z, Song-Jian A, et al. (2014) The Paleoproterozoic Chibaisong Mafic-Ultramafic Intrusion and Cu-Ni Deposit, North China Craton: SHRIMP Zircon U-Pband Re-Os Geochronology and Geodynamic Implications. J Geophys Remote Sensing 3: 116. doi:10.4172/2169-0049.1000116

27. Lu XP, Wu FY, Guo JH, Wilde SA, Yang JH, et al. (2006) Zircon U-Pb geochronological constraints on the Paleoproterozoic crustal evolution of the Eastern block in the North China Craton. Precambrian Res 146: 138-164.

28. Tang ZL, Yan HQ, Jiao JG, Li XH (2006) New classification of magmatic sulfide deposits in China and ore-forming processes of small intrusive bodies. Mineral Deposit 25: 1-9.

29. Compston W, Williams IS, Kirschvink JL (1992) Zircon U-Pb ages for the early Cambrian time-scale. J Geol Soc London 149: 171-184.

30. Liu DY, Jian P, Zhang FQ, Shi YR, Shi GH, et al. (2003) SHRIMP dating of adakites in the Tulinkai ophiolite Inner Mongolia: evidence for the early Paleozoic subduction. Acta Geologica Sinica 77: 317-327.

31. Song B, Zhang YH, Wan YS (2002) Mount making and procedure of the SHRIMP dating. Geology Review 48: 26-30.

32. Williams IS (1998) U-Th-Pb geochronology by ion microprobe. In: McKibben MA, Shanks III WC, Ridley WI (Eds.), Applications of Microanalytical Techniques to Understanding Mineralizing Processes. Rev Econ Geol 7: 1-35.

33. Miao LC, Qiu YM, McNaughton N, Luo ZK, Groves D, et al. (2002) SHRIMP $\mathrm{U}-\mathrm{Pb}$ zircon geochronology of granitoids from Dongping area, Hebei Province, China: constraints on tectonic evolution and geodynamic setting for gold metallogeny. Ore Geol Rev 19: 187-204.

34. Ludwig KR (2003) User's Manual for Isoplot 3.00: A Geochronological Toolkit for Microsoft Excel. Berkeley Geochronology Center Special Publication 4.

35. Shirey SB, Walker RJ (1995) Carius tube digestion for low-blank rheniumosmium analysis. Analtical Chemistry 67: 2136-2141

36. Stein HJ, Sundblad K, Markey RJ, Morgan MJ (1998) Re-Os ages for Archaean molybdenite and pyrite, Kuittila-Kivisuo, Finland, and Proterozoic molybdenite Lithuania: Testing the chronometer in a metamorphic and metasomatic setting. Mineralium Deposita 33: 329-345.

37. Markey R, Stein H, Morgan J (1998) Highly precise Re-Os dating for molybdenite using alkaline fusion and NTIMS. Talanta 45: 935-946.

38. Du AD, Wu SQ, Sun DZ, Wang SX, Qu WJ, et al. (2004) Preparation and certification of Re-Os dating reference materials: molybdenite HLP and JDC. Geostandard Geoanalysis Research 28: 41-52

39. Jaffey AH, Flymn KF, Glendenin LE, Bentley WC, ESSLING AM (1971) Precision measurement of half-lives and specific activities of ${ }^{235} \mathrm{U}$ and ${ }^{238} \mathrm{U}$. Physics Reviews 4: 1889-1906.

40. Smoliar ML, Walker RJ, Morgan JW (1996) Re-Os ages of group IIA, IIIA, IVA and VIB iron meteorites. Science 271: 1099-1102.

41. Lambert DD, Foster JG., Frick LR, Li C, Naldrett AJ (1999) Re-Os isotopic systematics of the Voisey's Bay Ni-Cu-Co magmatic ore system, Labrador, Canada. Lithos 47: 69-88.

42. Foster G, Lambert DD, Frick LR, Maas R (1996) Re-Os isotopic evidence for genesis of Archaean nickel ores from uncontaminated komatiites. Nature 382: 703-706.

43. Ruiz J, Mathur R (1999) Metallogenesis in continental margin: Re-Os evidence from porphyry copper deposits in Chile. In: LAMBERT D, RUIZ J (Eds.), Application of radiogenic isotopes to ore deposit research and exploration. Rev Econ Geol 12: 59-72

44. Meisel T, Walker RJ, Irving AJ, Lorand JP (2001) Osmium isotopic compositions of mantle xenoliths: a global perspective. Geochimica et Cosmochimica Acta 63: 1311-1323.

45. Barra F, Ruiz J, Mathur R, Titley S (2003) A Re-Os study of sulfide minerals from the Bagdad porphyry Cu-Mo deposit, northern Arizona, USA. Mineralium Deposita 38: 585-596.

46. Walker RJ, Morgan JW, Horan MF, Czamanske GK, Krogstad EJ, et al. (1994) $\mathrm{Re}-\mathrm{Os}$ isotopic evidence for an enriched-mantle source for the Noril'sk-type, ore-bearing intrusions, Siberia. Geochimica et Cosmochimica Acta 58: 41794197.

47. Walker RJ, Morgan JW, Hanski E, Smolkin VF (1997) Re-Os systematics of early Proterozoic ferropicrites, Pechenga Complex, NW Russia: evidence for ancient 1870s-enriched plumes. Geochimica et Cosmochimica Acta 61: 31453160 .

48. Walker RJ, Carlson RW, Shirey SB, Boyd FR (1989) Os, Sr, Nd and Pb isotope systematics of southern African peridotite xenoliths: Implications for the chemical evolution of subcontinental mantle. Geochimica et Cosmochimica Acta 53: 1583-1595.

49. Mao JW, Du AD (2002) The 982 Ma Re-Os age of copper-nickel sulfide ores in the Baotan area, Guangxi and its geological significances. Science of China 45: $911-920$.

50. Brooks CK, Keays RR, Lambert DD, Frick LR, Nielsen TFD (1999) Re-Os isotope geochemistry of Tertiary picritic and basaltic magmatism of East Greenland: constraints on plume-lithosphere interactions and the genesis of the Platinova reef, Skaergaard intrusion. Lithos 47: 107-126.

51. Yang SH, Zhou MF, Lightfoot PC, Malpas J, Qu WJ, et al. (2012) Selective crustal contamination and decoupling of lithophile and chalcophile element isotopes in sulfide-bearing mafic intrusions: An example from the Jingbulake Intrusion, Xinjiang, NW China. Chemical Geology 302-303: 106-118.

52. Fu DB (1994) A genetic model for ore magma of the Chibaisong copper-nicke sulphide deposit, Jilin. Acta Geologica Sinica 7: 401-416.

53. Peng P, Zhai MG, Zhang HF, Guo JH (2005) Geochronological constraints on the Paleoproterozoic evolution of the North China craton: SHRIMP zircon ages of different types of mafic dikes. Int Geol Rev 47: 492-508.

54. Luo Y, Sun M, Zhao GC, Li SZ, Xu P, et al. (2004) LA-ICP-MS U-Pb zircon age of the Liaohe Group in the Eastern Block of the North China Craton: constraints on the evolution of the Jiao-Liao-Ji Belt. Precambrian Res 134: 349-371.

55. Luo Y, Sun M, Zhao GC, Ayers JC, Li SZ, et al. (2008) A comparison of U-Pb and $\mathrm{Hf}$ isotopic compositions of detrital zircons from the North and South Liaohe Group: constraints on the evolution of the Jiao-Liao-Ji Belt, North China Craton. Precambrian Research 163: 279-306.

56. Lambert DD, Walker RJ, Morgan JW (1994) Re-Os and Sm-Nd isotope geochemistry of the Stillwater complex, Montana: implications for the petrogenesis of the J-M Reef. J Petrol 35: 1717-1753.

57. Ripley EM, Lambert DD, Frick LR (1998) Re-Os, Sm-Nd, and Pb isotopic constraints on mantle and crustal contributions to magmatic sulfide mineralization in the Duluth Complex. Geochimica et Cosmochimica Acta 62 3349-3365.

58. Walker RJ, Morgan JW, Naldrett AJ, Li C, et al. (1991) Re-Os isotope systematics of $\mathrm{Ni}$-Cu sulfide ores, Sudbury igneous complex, Ontario: Evidence for a major crustal component. Earth and Planetary Science Letters 105: 416429 .

59. Walker RJ, Shirey SB, Stecher O (1988) Comparative Re-Os, Sm-Nd and Rb$\mathrm{Sr}$ isotope and trace element systematics for Archean kaomatites flows from Munro Township, Abitibi belt, Ontario. Earth and Planetary Science Letters 87: $1-2$

60. Martin CE (1989) Re-Os isotopic investigation of the Stillwater Complex Montana. Earth and Planetary Science Letters 93: 336-344.

61. Martin CE (1991) Osmium isotopic characteristics of mantle-derived rocks Geochimica et Cosmochimica Acta 55: 1421-1434.

62. Snow JE, Reisberg L (1995) Os isotope systematics of the MORB mantle: Results from altered abyssal peridotites. Earth and Planetary Science Letters 133: $411-421$ 